\title{
Anthropometry Dimensions of Older Malaysians:

\author{
Comparison of Age, Gender and Ethnicity
}

\author{
Rosnah M.Y., Mohd Rizal H. \& Sharifah_Norazizan S.A.R. \\ Institute of Gerontology, Universiti Putra Malaysia, MALAYSIA \\ E-mail: rosnah@eng.upm.edu.my
}

\begin{abstract}
Studies have indicated that body dimensions differ for various populations. To determine whether there are differences in the anthropometric data of the elderly population in Malaysia, the anthropometric data collected from a previous project was used. These comparisons can give some indications of the relative sizes between age, gender and ethnicity in Malaysian elderly populations. The results showed that some anthropometric dimensions were influenced by age, gender and ethnicity. Regression analysis showed that age and ethnicity were significant predictors $(\mathrm{p}<.01)$ of Malaysians elderly BMI's. The analysis has provided important information in designing and planning of facilities and products for elderly populations.
\end{abstract}

Keywords: Anthropometry dimensions, Older Malaysians, BMI's, Demographic background

\section{Introduction}

The population of today's world is rapidly ageing. Elderly populations have grown because of worldwide improvements in health services, educational status, and economic development (Kinsella \& Victoria, 2001). The number of persons aged 60 years or over is estimated to be 688 million in 2006 and is projected to grow to almost 2 billion by 2050 (United Nations, 2006). Even though Malaysia's population is not currently aged, this will change over the next two decades. Malaysia is expected to increase its percentage of older persons to more than $7 \%$ in 2010 and $9.8 \%$ in 2020 (Pala, 1998).

With increasing ageing trends, it is necessary to consider older people's cognitive strengths, capabilities and physical limitations in the planning or design of products for daily use. Therefore, their anthropometric characteristics must be quantified. Besides, anthropometric measurements are also important indicators of an individual nutritional status. The ageing process involves modifications in nutritional and physiological status, such as a decrease in body weight and height (Dey et al., 1999) and also a declining in fat-free mass associated with an increase in fat mass. Body composition changes occur differently in males and females and in the various phases of ageing, influencing anthropometry. Consequently, the anthropometric standard values derived from adult population may not be applicable to the elderly.

There is very little information about anthropometric data of older persons, especially in developing countries. Only more recently have population studies included specific data on individuals 75 years of age and older (Kuczmarski et al., 2000; Perissinotto et al., 2002; Velasquez-Alva et al., 2003; Santos et al., 2004). Fozard (1981) and Stoudt (1981) have pointed out that older people differ anthropometrically with inter-individual variance increasing with age. Hence anthropometric data available for younger generation cannot be used even with allowances for the age-related changes for the elderly population. Another complicating factor is the ethnic mix, which could be very different in the elderly population compared to the young adult population.

Since Malaysia is a multi-racial, multi-ethnic country, comparison of the anthropometric dimensions between its populations is useful. Age, gender and ethnicity differences of anthropometric dimensions of the Malaysians elderly will not only help to explain the ageing process of each group, but also to determine the group at risk and thus, attention can be directed to this group.

\section{Methodology}

In this study, 39 body dimensions of 230 older Malaysians comprising males $(\mathrm{N}=129)$ and females $(\mathrm{N}=101)$ and Malays $(\mathrm{N}=174)$ and non-Malays $(\mathrm{N}=56)$ were obtained from an earlier study entitled 'An Elderly Friendly Housing Environment for Older Malaysians' by the Institute of Gerontology, Universiti Putra Malaysia. Body mass Index (BMI, 
weight/height ${ }^{2}$ ) was calculated and categorized from same data into four groups (underweight, normal, overweight and obesity) using the World Health Organization (WHO) standard method. The BMI represents the easiest and most frequently used index to identify subjects at risk for under-or over-nutrition. Data was analyzed using Statistical Package for the Social Sciences (SPSS). Level of significance used for the data was set at $\mathrm{p}<0.05$ (two-tailed).

2.1 Comparisons were made for anthropometry and Body Mass Index (BMI) between:

i. $\quad$ Males(m) and females (f)

ii. Malays(ma) and non-Malays(nma)

T-Test analysis was performed to identify gender and ethnicity differences in anthropometric dimensions. Male and female or Malay and Non-Malay were treated as two independent groups and the null-hypothesis tested the difference in the mean of each anthropometric dimensions between older women and older men or older Malay and older Non-Malay $\left(\mathrm{H}_{0}: \mu_{1(\mathrm{~m} / \mathrm{rma})}-\mu_{2(\mathrm{f} / \mathrm{rma})}=0\right)$.

Chi-square analysis was used to measure the level of relationship between gender and ethnicity in BMI categories. Use of chi-square deals with the situation in which we have two variables (gender and BMI categories or ethnicity and BMI categories) and to determine whether these variables are independent of one another $\left(\mathrm{H}_{0}\right.$ : Independence between two variables).

\subsection{Correlation between Age and Anthropometric dimension}

To compare whether there is a significant correlation between age and the anthropometric dimensions of the Malaysian elderly, the null-hypothesis $\left(\mathrm{H}_{0}: \rho=0\right)$ to test the significance of the relationship between the two variables was performed.

\subsection{Relationship between Age and BMI Category}

ANOVA test was used to identify the relationship between BMI categories and age. The null-hypothesis is $\left(\mathrm{H}_{0}\right.$ : $\left.\mu_{1}=\mu_{2}=\mu_{3}=\mu_{4}\right)$ was tested.

\subsection{Relationship between age, gender and ethnicity with BMI}

As for correlation, regression is also used to study relationships between interval-ratio variables in which a single dependent (criterion) variable is regressed with one or several independent (predictor) variables.

\section{Results and Discussions}

\subsection{Comparison between Male and Female Anthropometric Dimensions}

The results of anthropometric dimensions (mean value, standard deviation and t-test) for males and females were presented in Table 1. Analysis showed that there were significant differences $(p<0.01)$ in all anthropometric measurements between elderly men and women except for standing hip breadth. This finding was supported by a previous study by Haitao et al. (2007) where there is no significant difference between male and female elderly in the hip area dimension. For all measurements, the male dimensions exceeded the females except for hip breadth and standing chest depth.

\subsection{Comparison between Malay and Non-Malay Anthropometric Dimensions}

Analysis in Table 2 shows significant differences between Malay and Non-Malays in term of weight ( $\mathrm{t}=2.819$, $\mathrm{p}<0.01)$, kneecap height, standing $(\mathrm{t}=-4.021, \mathrm{p}<0.01)$, eye height, standing $(\mathrm{t}=-2.260, \mathrm{p}<0.05)$, elbow height, standing $(\mathrm{t}=-3.183, \mathrm{p}<0.01)$, sitting height $(\mathrm{t}=-3.254, \mathrm{p}<0.01)$, eye height, sitting $(\mathrm{t}=-3.049, \mathrm{p}<0.01)$, shoulder height, sitting $(\mathrm{t}=-2.652, \mathrm{p}<0.01)$, popliteal height, sitting $(\mathrm{t}=-2.185, \mathrm{p}<0.05)$, hip breadth, standing $(\mathrm{t}=2.703, \mathrm{p}<0.01)$, buttock-popliteal length, sitting $(\mathrm{t}=2.771, \quad \mathrm{p}<0.01)$, shoulder-elbow length, $\quad$ sitting $(\mathrm{t}=-2.861, \quad \mathrm{p}<0.01)$, span horizontal $(\mathrm{t}=-2.035, \mathrm{p}<0.05)$, thigh thickness, $\operatorname{sitting}(\mathrm{t}=2.911, \mathrm{p}<0.01)$ and foot breadth $(\mathrm{t}=2.179, \mathrm{p}<0.05)$. Comparison between Chinese (Beijing) and Japanese elderly also showed that the anthropometric dimensions differences were found between this two groups (Haitao et al., 2007. It is observed that in almost all the measurements, the Non-Malays showed a higher reading compared to the Malays except for weight. The Malays are heavier and shorter. The significant differences in many of the measurements clearly indicate that ethnicity should be taken into consideration when designing within the Malaysian population.

\subsection{Comparison between Male and Female Body Mass Index (BMI)}

BMI differences were also found between gender in the four groups $\left(x^{2}=13.260, \mathrm{df}=3, \mathrm{p}=0.004\right)$. About $50 \%$ of the male elderly were in the overweight and obesity group compared with the female elderly of $60 \%$. The problem of obesity was more frequent in elderly women (26.7\%) (Table 3). Based on Lenore (1996) in his study, women had a higher mean BMI and standard deviation than men. This clearly indicates that those belonging to these categories are at risks, with elderly females having higher risks. Probably as female aged, they become more sedentary. Thus, the lifestyles and nutrition of this group has to change. 


\subsection{Comparison between Malay and Non-Malay Body Mass Index (BMI)}

Table 4 shows a significant relationship $\left(x^{2}=16.580, \mathrm{df}=3, \mathrm{p}=0.001\right)$ between Malays and Non-Malays with the BMI category. Even though, this relationship seems very low (Cramer's V=.268), most Malay elderly have obesity and overweight problems than Non-Malays. Finding from a previous study also showed that there was a significant difference between ethnicity and BMI. The range of overweight among elderly women in Hong Kong was $2.5 \%$ compared to $53.5 \%$ in Barbados elderly women (Lenore, 1996). The reasons for the greater health risks posed by the Malays in this category, though maybe contributed by the unhealthy lifestyle including diet have to be studied further.

\subsection{Correlation between Age and Anthropometric Dimensions}

There were significant relationships between age and weight $(\mathrm{r}=-.171, \mathrm{p}=0.009)$, kneecap height, standing ( $\mathrm{r}=.210$, $\mathrm{p}=0.001)$, chest depth, standing $(\mathrm{r}=-.153, \mathrm{p}=0.02)$, hip breath, sitting $(\mathrm{r}=-.136, \mathrm{p}=0.04)$, thigh thickness, sitting $(\mathrm{r}=-.146$, $\mathrm{p}=0.027)$ and grip strength $(\mathrm{r}=-.151, \mathrm{p}=0.022)$ (Table 3$)$. An assumption can be made from this result is that the changes of body dimension are also related with increasing age. The negative correlation values showed that as age increases, these measurement decreases. A study by Bryna et al. (2001) on anthropometry changes among elderly Canadians found that body weight and stature declined with aging, particularly in the very old and those with dementia. Perissinotto et al. (2002) also showed that weight significantly decreased with age among elderly Italian population.

\subsection{Relationship between Age and Body Mass Index (BMI)}

Table 6 shows significant differences in age between the different BMI category $(\mathrm{F}=3.811$, $\mathrm{p}=0.05)$. Most of young elderly have health problems in term of obesity and overweight (figure 1). These findings were similar to the results stated by Jeffrey (2005) where individuals aged 75 and older were the least likely to be overweight or obese as compared with other lower age groups.

\subsection{Relationship between Age, Gender and Ethnicity with Body Mass Index}

Three predictor variables accounted for $6.7 \%$ of variance in the Body Mass Index Category $(\mathrm{F}=10.918, \mathrm{df}=3, \mathrm{p}=.000)$. Regression shows (see Table 7) that age and ethnicity are significant predictors $(\mathrm{p}<.01)$ of BMI. Increasing age will reduce BMI values among the elderly. In ethnicity, overweight and obesity mostly tend to happen among Malay than Non-Malay. Otherwise, gender has no significant influence on Body Mass Index among older persons.

\section{Conclusion}

This study has shown that the anthropometric dimensions and Body Mass Index (BMI) is closely linked with some demographic background. Age and ethnicity remains the best predictor for elderly BMI in Malaysia. Considerations on these factors are very important when designing products, facilities or tools to meet the needs and wants elderly population. Therefore, by providing this empirical data it can be useful for dietitians, clinicians and other groups whose work are related to ageing and elderly. The study reinforces the findings of some other studies that showed elderly women are more at health risks due to overweight and obesity compared to elderly men. The study also clearly identified that the Malays were at higher health risks as compared to the non-Malays. This call for a change of lifestyles and diet as these are the two most common causes of overweight and obesity among populations.

\section{References}

Barbosa, A.R., José M.P. Sauza, M.L. Lebrão, R. Laurenti and M.F.N. Marucci. (2005). Anthropometry of elderly residents in the city of São Paulo, Brazil. Cad. Saúde Pública, Rio de Janeiro, 21(6), 1929-1938.

Bryna, S., Marie-Jeanne, K. \& Sylvie, N. (2001). Anthropometric Changes Over 5 Years in Elderly Canadian by Age, Gender and Cognitive Status. Journal of Gerontology: Biological Sciences and Medical Sciences, 56, $483-488$.

Dey D.K., Rothenberg E., Sundh V., Bosaeus I. \& Steen B. (1999). Height and body weight in the elderly. I A 25 year longitudinal study of population aged 70-95 years. European Journal of Clinical Nutrition, 53, 905-914.

Fozard, J.L. (1981). Person-environment relationships in adulthood: Implications for human factor engineering. Human Factors, 23, 7-27.

Ghosh, J. R., Z. Khatoon, P. Bhattacharjee and A. R. Bandyopadhyay (2005). A Comparative Study on Anthropometric Variables in Two Communities of West Bengal, India. Anthropologist, 7(3), 217-219.

Haitao, H., Zhizhong, L., Jingbin, Y., Xiaofang, W., Hui, X., Jiyang, D. \& Li, Z. (2007). Anthropometric Measurement of the Chinese Elderly Living in the Beijing. Int. Journal of Industrial Ergonomics, 37(4), 303-311.

Jeffrey, A.R. Overweight and Obese Elderly and Near Elderly in the United States. (2002). Estimates for the Noninstitutionalized Population Age 55 and Older. Statistical Brief \#68. February 2005. Agency for Healthcare Research and Quality, Rockville, MD. [Online] Available: http://www.meps.ahrq.gov/papers/st68/stat68.pdf.

Kinsella, Kevin and Victoria A. Velkoff. U.S. Census Bureau. (2001). Series P95/01-1, An Aging World: 2001, U.S. Government Printing Office, Washington, DC. 
Kothiyal K. \& Tettey S. (2001). Anthropometry for Design for the Elderly. Int J Occup Saf Ergon, 17(1), 15-34.

Kuczmarski M.F., Kuczmarski R.J., Najjar M. (2000). Descriptive anthropometric references data for older Americans. J Am Diet Assoc, 100, 59-66.

Lenore, J.L. (1996). Weight, height and body mass index distributions in geographically and ethnically diverse samples of older persons. Age and Ageing, 25(4), 300-306.

Pala, J. (1998). Population ageing trends in Malaysia. Monograph Series. Department of Statistics, Malaysia.

Perissinotto, E., C. Pisent, G. Sergi, F. Grigoletto and G. Enzi. (2001). Anthropometric measurements in the elderly: age and gender differences. British J of Nutrition; 87, 177-186.

Rosnah, M.Y., S.A.R. Sharifah Norazizan, S.H. Nurazrul, H. Tengku Aizan, H.H. Ahmad, M.S. Aini, G.S.C. Lina, W.C. Lo and H. Mohd Rizal. (2006). Comparison of Elderly Anthropometry Dimensions amongst various Populations. Asia-Pacific J of Pub Health, 18 Supp, 20-25.

Santos J.L., Albala C., Lera L., Garcia C., Arroyo P., Perez-Bravo F. (2004). Anthropometric measurements in the elderly population of Santiago, Chile. Nutrition, 20, 452-457.

Stoudt, H.W. (1981). The anthropometry of the elderly. Human Factors, 23, 29-37.

Suriah A.R., Zalifah M.K., Zainorni M.J., Shafawi S., Mimie Suraya S., Zarina N. and Wan Zainuddin W.A. (1998). Anthropometric measurements of the elderly. Mal J Nut, 4, 55-63.

United Nations. (2006). Population Ageing 2006. Department of Economic and Social Affairs. Population Division. United Nations Publication, Sales No. E.06.XIII.2.

Velasquez-Alva M.C., Irigoyen C.M.E., Zepeda Z.M., Sanchez M.V.M., Garcia J.L. \& Cisneros M.P. (2003). Anthropometric measurement of sixty-year and older Mexican urban group. J Nutr Health Aging, 7, 1-5.

W.S. Yap, C.C. Chan, S.P. Chan and Y.T. Wang. (2001). Ethnic differences in anthropometry among adult Singaporean Chinese, Malays and Indians, and their effect on lung volumes. Respiratory Medicine, 95, 297-304. 
Table 1. Mean, standard deviation and t-test for anthropometric dimensions of older Malaysians males and females aged 60 and above $(n=230)$

\begin{tabular}{|c|c|c|c|c|c|c|}
\hline \multirow[b]{2}{*}{ Dimensions (cm) } & \multicolumn{2}{|c|}{ Male, $\mathrm{N}=129$} & \multicolumn{2}{|c|}{ Female, $N=101$} & \multicolumn{2}{|c|}{ Independent t-test } \\
\hline & Mean & Std.Dev & Mean & Std. Dev & $\mathbf{t}$ & $\mathbf{p}$ \\
\hline 1.Weight $(\mathrm{Kg})$ & 66.6 & 11.3 & 60.0 & 13.8 & 4.002 & 0.000 \\
\hline 2.Height & 162.3 & 7.5 & 149.0 & 5.8 & 14.724 & 0.000 \\
\hline 3.Coat Height, Standing & 139.2 & 6.0 & 127.3 & 5.4 & 15.695 & 0.000 \\
\hline 4.Shoulder Height, Standing & 134.7 & 5.8 & 122.0 & 5.3 & 17.221 & 0.000 \\
\hline 5. Waist Height, Standing & 94.1 & 5.6 & 88.4 & 4.5 & 8.310 & 0.000 \\
\hline 6.Crotch Height, Standing & 71.0 & 4.0 & 65.9 & 4.3 & 9.399 & 0.000 \\
\hline 7.Kneecap Height, Standing & 50.0 & 3.3 & 44.3 & 2.9 & 13.579 & 0.000 \\
\hline 8.Eye Height, Standing & 149.9 & 6.1 & 136.4 & 5.8 & 17.100 & 0.000 \\
\hline 9.Elbow Height, Standing & 97.1 & 5.8 & 89.2 & 4.4 & 11.333 & 0.000 \\
\hline 10.Sitting Height & 83.1 & 4.3 & 76.4 & 3.8 & 12.335 & 0.000 \\
\hline 11.Eye Height, Sitting & 71.6 & 5.6 & 65.0 & 3.8 & 10.266 & 0.000 \\
\hline 12.Shoulder Height, Sitting & 56.7 & 3.5 & 50.6 & 5.7 & 9.993 & 0.000 \\
\hline 13.Knee Height, Sitting & 49.8 & 2.9 & 45.1 & 2.1 & 13.682 & 0.000 \\
\hline 14.Popliteal Height, Sitting & 39.6 & 2.4 & 36.5 & 1.7 & 10.961 & 0.000 \\
\hline 15.Arm Reach Upward, Sitting & 126.6 & 5.7 & 108.4 & 10.7 & 16.636 & 0.000 \\
\hline 16.Hip Breadth, Standing & 31.5 & 2.4 & 32.0 & 3.1 & -1.313 & 0.191 \\
\hline 17.Chest (Bust) Depth, Standing & 23.1 & 2.6 & 25.9 & 3.6 & -6.607 & 0.000 \\
\hline 18.Shoulder Breadth, Sitting & 41.9 & 3.4 & 37.0 & 3.0 & 11.491 & 0.000 \\
\hline 19.Hip Breath, Sitting & 35.0 & 3.5 & 33.3 & 4.0 & 3.506 & 0.001 \\
\hline $\begin{array}{l}\text { 20.Forearm-Hand Length (Elbow-Finger } \\
\text { Tip Length), Sitting }\end{array}$ & 45.5 & 2.0 & 42.2 & 2.6 & 10.595 & 0.000 \\
\hline 21.Buttock-Knee Length, Sitting & 53.7 & 3.6 & 52.4 & 2.8 & 2.872 & 0.004 \\
\hline 22.Buttock-Popliteal Length, Sitting & 45.5 & 2.7 & 42.4 & 2.8 & 8.476 & 0.000 \\
\hline 23.Shoulder-Elbow Length, Sitting & 35.7 & 1.9 & 32.9 & 1.8 & 11.182 & 0.000 \\
\hline 24.Arm Reach Forward, Sitting & 76.2 & 5.6 & 69.7 & 5.2 & 9.060 & 0.000 \\
\hline 25.Shoulder Grip Length, Sitting & 63.5 & 4.2 & 57.8 & 4.5 & 9.837 & 0.000 \\
\hline 26.Upper Limb Length & 72.3 & 3.7 & 66.6 & 3.7 & 11.641 & 0.000 \\
\hline 27.Span Horizontal & 169.1 & 7.9 & 156.4 & 7.3 & 12.515 & 0.000 \\
\hline 28.Elbow Span & 90.8 & 4.1 & 82.0 & 5.2 & 13.881 & 0.000 \\
\hline 29.Thigh Thickness, Sitting & 14.6 & 2.2 & 12.8 & 2.3 & 6.046 & 0.000 \\
\hline 30.Hand Length & 17.8 & 1.2 & 16.4 & 1.1 & 9.286 & 0.000 \\
\hline 31.Palm Length & 10.3 & 1.0 & 9.4 & 1.1 & 6.731 & 0.000 \\
\hline 32.Hand Breadth & 8.6 & 0.5 & 7.7 & 0.4 & 15.064 & 0.000 \\
\hline 33.Foot Length & 24.6 & 1.1 & 22.4 & 2.0 & 10.695 & 0.000 \\
\hline 34.Instep Length & 18.4 & 1.3 & 16.4 & 1.1 & 12.536 & 0.000 \\
\hline 35.Foot Breadth & 10.2 & 0.7 & 9.0 & 0.6 & 13.715 & 0.000 \\
\hline 36.Heel Breadth & 6.5 & 0.7 & 6.1 & 0.6 & 4.764 & 0.000 \\
\hline 37.Thumb Strength $(\mathrm{Kg} / \mathrm{N})$ & 7.9 & 1.7 & 4.5 & 1.4 & 16.759 & 0.000 \\
\hline 38.Grip Strength $(\mathrm{Kg} / \mathrm{N})$ & 31.5 & 7.7 & 17.5 & 5.9 & 15.487 & 0.000 \\
\hline 39.Arm Reach Upward, Standing & 247.4 & 9.9 & 227.8 & 8.2 & 15.990 & 0.000 \\
\hline
\end{tabular}

** significant at the 0.01 level $(2$-tailed $)$

* significant at the 0.05 level $(2$-tailed $)$ 
Table 2. T-test for anthropometric dimensions and ethnicity among older Malaysians (male and female) aged 60 years and above

\begin{tabular}{|c|c|c|c|c|c|c|}
\hline \multirow[b]{2}{*}{ Dimensions $(\mathrm{cm})$} & \multicolumn{2}{|c|}{ Malay, $\mathrm{N}=174$} & \multicolumn{2}{|c|}{ Non-Malay, $\mathrm{N}=56$} & \multicolumn{2}{|c|}{ Independent t-test } \\
\hline & Mean & Std. Dev & Mean & Std. Dev & $\mathrm{t}$ & $\mathrm{p}$ \\
\hline 1.Weight $(\mathrm{Kg})$ & 64.998 & 13.074 & 59.511 & 11.302 & 2.819 & $.005^{* *}$ \\
\hline 2. Height & 155.782 & 9.550 & 158.600 & 8.881 & -1.953 & .052 \\
\hline 3. Coat Height, Standing & 133.365 & 7.959 & 135.884 & 8.840 & -1.899 & .061 \\
\hline 4. Shoulder Height, Standing & 128.529 & 8.324 & 131.018 & 8.563 & -1.933 & .055 \\
\hline 5. Waist Height, Standing & 91.534 & 6.095 & 91.833 & 5.232 & -.329 & .742 \\
\hline 6. Crotch Height, Standing & 68.582 & 4.650 & 69.330 & 5.367 & -1.006 & .316 \\
\hline 7. Kneecap Height, Standing & 46.891 & 4.097 & 49.416 & 4.058 & -4.021 & $.000 * *$ \\
\hline 8. Eye Height, Standing & 143.224 & 8.997 & 146.311 & 8.549 & -2.260 & $.025^{*}$ \\
\hline 9. Elbow Height, Standing & 92.895 & 6.586 & 96.023 & 5.759 & -3.183 & $.002 * *$ \\
\hline 10. Sitting Height & 79.509 & 5.187 & 82.082 & 5.027 & -3.254 & $.001 * *$ \\
\hline 11. Eye Height, Sitting & 68.054 & 5.405 & 70.766 & 6.857 & -2.260 & $.025^{*}$ \\
\hline 12. Shoulder Height, Sitting & 53.553 & 5.614 & 55.618 & 4.881 & -3.183 & $.002 * *$ \\
\hline 13. Knee Height, Sitting & 47.483 & 3.324 & 48.425 & 3.978 & -3.254 & $.001 * *$ \\
\hline 14. Popliteal Height, Sitting & 38.056 & 2.489 & 38.921 & 2.839 & -3.049 & $.003 * *$ \\
\hline 15. Arm Reach Upward, Sitting & 118.053 & 12.691 & 120.420 & 10.549 & -2.652 & $.009 *$ \\
\hline 16. Hip Breadth, Standing & 32.011 & 2.750 & 30.895 & 2.475 & -1.756 & .080 \\
\hline 17. Chest (Bust) Depth, Standing & 24.530 & 3.557 & 23.664 & 2.801 & -2.185 & $.030^{*}$ \\
\hline 18. Shoulder Breadth, Sitting & 40.034 & 4.085 & 38.909 & 3.767 & -1.261 & .208 \\
\hline 19. Hip Breath, Sitting & 34.545 & 3.493 & 33.473 & 4.579 & 2.703 & $.007 * *$ \\
\hline $\begin{array}{lcr}20 . & \text { Forearm-Hand } \quad \text { Length } \\
\text { (Elbow-Finger Tip Length), Sitting }\end{array}$ & 44.104 & 2.682 & 43.963 & 3.099 & 1.661 & .098 \\
\hline 21. Buttock-Knee Length, Sitting & 53.298 & 3.321 & 52.584 & 3.367 & 1.903 & .060 \\
\hline 22. Buttock-Popliteal Length, Sitting & 44.491 & 2.952 & 43.166 & 3.568 & 1.844 & .067 \\
\hline 23. Shoulder-Elbow Length, Sitting & 34.241 & 2.328 & 35.236 & 2.055 & .332 & .740 \\
\hline 24. Arm Reach Forward, Sitting & 73.494 & 6.258 & 73.033 & 6.448 & 1.396 & .164 \\
\hline 25. Shoulder Grip Length, Sitting & 61.068 & 5.154 & 60.718 & 5.125 & 2.771 & $.006^{* *}$ \\
\hline 26. Upper Limb Length & 69.717 & 4.494 & 69.986 & 5.263 & -2.861 & $.005^{* *}$ \\
\hline 27. Span Horizontal & 162.747 & 9.440 & 165.816 & 10.922 & .475 & .635 \\
\hline 28. Elbow Span & 86.640 & 6.627 & 87.916 & 5.253 & .444 & .658 \\
\hline 29. Thigh Thickness, Sitting & 14.086 & 2.455 & 13.021 & 2.124 & -.373 & .709 \\
\hline 30. Hand Length & 17.172 & 1.253 & 17.156 & 1.561 & -2.035 & $.043^{*}$ \\
\hline 31. Palm Length & 9.916 & 1.230 & 9.952 & .8983 & -1.314 & .190 \\
\hline 32. Hand Breadth & 8.204 & .630 & 8.084 & .561 & 1.269 & .206 \\
\hline 33. Foot Length & 23.644 & 1.903 & 23.695 & 1.907 & -.175 & .861 \\
\hline 34. Instep Length & 17.506 & 1.582 & 17.670 & 1.566 & -.677 & .501 \\
\hline 35. Foot Breadth & 9.717 & .899 & 9.414 & .917 & 2.179 & $.030^{*}$ \\
\hline 36. Heel Breadth & 6.341 & .670 & 6.247 & .679 & .911 & .363 \\
\hline 37. Thumb Strength $(\mathrm{Kg} / \mathrm{N})$ & 6.266 & 2.213 & 6.777 & 2.663 & -1.426 & .155 \\
\hline 38. Grip Strength $(\mathrm{Kg} / \mathrm{N})$ & 25.298 & 9.484 & 25.446 & 11.000 & -.098 & .922 \\
\hline 39. Arm Reach Upward, Standing & 237.940 & 13.230 & 241.480 & 13.768 & -1.690 & .094 \\
\hline
\end{tabular}

** significant at the 0.01 level $(2$-tailed $)$

* significant at the 0.05 level $(2$-tailed $)$ 
Table 3. Relationship between Body Mass Index (BMI) category and gender $(n=230)$

\begin{tabular}{|c|c|c|c|c|c|}
\hline \multirow{2}{*}{ Gender } & \multicolumn{4}{|c|}{ BMI Category } & \multirow[t]{2}{*}{ Total } \\
\hline & $\begin{array}{l}\text { Underweight } \\
\text { (Below 18.5) }\end{array}$ & $\begin{array}{c}\text { Normal } \\
(18.5-24.9)\end{array}$ & $\begin{array}{c}\text { Overweight } \\
(25.0-29.9)\end{array}$ & $\begin{array}{c}\text { Obesity } \\
\text { (30.0 and over) }\end{array}$ & \\
\hline \multirow[t]{2}{*}{ Male } & 5 & 60 & 51 & 13 & 129 \\
\hline & $3.9 \%$ & $46.5 \%$ & $39.5 \%$ & $10.1 \%$ & $100.0 \%$ \\
\hline \multirow{2}{*}{ Female } & 7 & 33 & 34 & 27 & 101 \\
\hline & $6.9 \%$ & $32.7 \%$ & $33.7 \%$ & $26.7 \%$ & $100.0 \%$ \\
\hline \multirow[t]{2}{*}{ Total } & 12 & 93 & 85 & 40 & 230 \\
\hline & $5.2 \%$ & $40.4 \%$ & $37.0 \%$ & $17.4 \%$ & $100.0 \%$ \\
\hline
\end{tabular}

$\mathrm{x}^{2}=13.260, \mathrm{df}=3, \mathrm{p}=0.004$

Table 4. Chi-square analysis of BMI Category between Malay and Non-Malay $(n=230)$

\begin{tabular}{|c|c|c|c|c|c|}
\hline \multirow[t]{2}{*}{$\begin{array}{l}\text { Ethnicity } \\
\text { groups }\end{array}$} & \multicolumn{4}{|c|}{ BMI Category } & \multirow[t]{2}{*}{ Total } \\
\hline & $\begin{array}{l}\text { Underweight } \\
\text { (Below 18.5) }\end{array}$ & $\begin{array}{c}\text { Normal } \\
(18.5-24.9)\end{array}$ & $\begin{array}{c}\text { Overweight } \\
(25.0-29.9)\end{array}$ & $\begin{array}{c}\text { Obesity } \\
\text { (30.0 and over) }\end{array}$ & \\
\hline \multirow[t]{2}{*}{ Malay } & 7 & 62 & 66 & 39 & 174 \\
\hline & $4.0 \%$ & $35.7 \%$ & $37.9 \%$ & $22.4 \%$ & $100.0 \%$ \\
\hline \multirow{2}{*}{ Non-Malay } & 5 & 31 & 19 & 1 & 56 \\
\hline & $8.9 \%$ & $55.4 \%$ & $33.9 \%$ & $1.8 \%$ & $100.0 \%$ \\
\hline \multirow[t]{2}{*}{ Total } & 12 & 93 & 85 & 40 & 230 \\
\hline & $5.2 \%$ & $40.4 \%$ & $36.9 \%$ & $17.5 \%$ & $100.0 \%$ \\
\hline
\end{tabular}

$\mathrm{x}^{2}=16.580, \mathrm{df}=3, \mathrm{p}=0.001$ Cramer's $\mathrm{V}=.268$

Table 5. Correlations-test for anthropometric measurements of older Malaysians males and females and age ( $\mathrm{n}=230$ )

\begin{tabular}{|c|c|c|}
\hline Anthropometric Dimensions & $\mathrm{r}$ & $\mathrm{p}$ \\
\hline 1. Weight (Kg) & $-.171 * *$ & .009 \\
\hline 2. Height & .025 & .708 \\
\hline 3. Coat Height, Standing & .023 & .725 \\
\hline 4. Shoulder Height, Standing & .020 & .759 \\
\hline 5. Waist Height, Standing & .064 & .331 \\
\hline 6. Crotch Height, Standing & .021 & .746 \\
\hline 7. Kneecap Height, Standing & $.210 * *$ & .001 \\
\hline 8. Eye Height, Standing & .035 & .597 \\
\hline 9. Elbow Height, Standing & .024 & .716 \\
\hline 10. Sitting Height & .018 & .787 \\
\hline 11. Eye Height, Sitting & .014 & .828 \\
\hline 12. Shoulder Height, Sitting & .036 & .584 \\
\hline 13. Knee Height, Sitting & .063 & .338 \\
\hline 14. Popliteal Height, Sitting & .037 & .572 \\
\hline 15. Arm Reach Upward, Sitting & .049 & .462 \\
\hline 16. Hip Breadth, Standing & -.118 & .075 \\
\hline 17. Chest (Bust) Depth, Standing & $-.153 *$ & .020 \\
\hline 18. Shoulder Breadth, Sitting & -.090 & .173 \\
\hline 19. Hip Breath, Sitting & $-.136^{*}$ & .040 \\
\hline 20. Forearm-Hand Length (Elbow-Finger Tip Length), Sitting & .053 & .423 \\
\hline 21. Buttock-Knee Length, Sitting & -.066 & .319 \\
\hline 22. Buttock-Popliteal Length, Sitting & .006 & .926 \\
\hline 23. Shoulder-Elbow Length, Sitting & .063 & .340 \\
\hline 24. Arm Reach Forward, Sitting & .008 & .906 \\
\hline 25. Shoulder Grip Length, Sitting & -.032 & 630 \\
\hline 26. Upper Limb Length & .036 & .583 \\
\hline
\end{tabular}




\begin{tabular}{|l|c|c|}
\hline 27. Span Horizontal & -.018 & .787 \\
\hline 28. Elbow Span & .037 & .578 \\
\hline 29. Thigh Thickness, Sitting & $-.146^{*}$ & .027 \\
\hline 30. Hand Length & .031 & .641 \\
\hline 31. Palm Length & .066 & .320 \\
\hline 32. Hand Breadth & .080 & .227 \\
\hline 33. Foot Length & .072 & .277 \\
\hline 34. Instep Length & .124 & .060 \\
\hline 35. Foot Breadth & .058 & .380 \\
\hline 36. Heel Breadth & .007 & .917 \\
\hline 37. Thumb Strength $(\mathrm{Kg} / \mathrm{N})$ & -.035 & .599 \\
\hline 38. Grip Strength $(\mathrm{Kg} / \mathrm{N})$ & $-.151^{*}$ & .022 \\
\hline 39. Arm Reach Upward, Standing & .036 & .590 \\
\hline
\end{tabular}

** Correlation is significant at the 0.01 level $(2$-tailed $)$

* Correlation is significant at the 0.05 level ( 2 -tailed)

Table 6. One-Way Analysis of Variance (ANOVA) for Body Mass Index (BMI) category and age among older Malaysians (male and female) aged 60 years and above

\begin{tabular}{|l|c|c|c|c|}
\hline \multicolumn{1}{|c|}{ Source } & $\underline{\mathrm{df}}$ & $\underline{\mathrm{SS}}$ & $\underline{\mathrm{MS}}$ & $\underline{\mathrm{F}}$ \\
\hline Between Groups & $\mathbf{3}$ & $\mathbf{2 9 9 . 3 8 3}$ & $\mathbf{9 9 . 7 9 4}$ & $\mathbf{3 . 8 1 1 *}^{*}$ \\
\hline Within Groups & 226 & 5918.465 & 26.188 & \\
\hline Total & 229 & 6217848 & & \\
\hline
\end{tabular}

$* \mathrm{p}<.05$

Table 7. Summary of Regression Analysis for Variables Predicting Elderly Body Mass Index ( $\mathrm{n}=230$ )

\begin{tabular}{|c|c|c|c|c|}
\hline Variable & $B$ & $S E B$ & B & $\mathbf{p}$ \\
\hline $\begin{array}{l}\mathrm{F}=10.918, \mathrm{df}=3, \mathrm{p}=.000 \\
\text { (Constant) }\end{array}$ & 4.471 & .672 & & .000 \\
\hline Age & -.031 & .010 & $-.195 * *$ & .002 \\
\hline Gender & -.192 & .104 & -.116 & .066 \\
\hline Ethnicity & .491 & .119 & $.256^{* *}$ & .000 \\
\hline
\end{tabular}

Note: $\mathrm{R}^{2}=.127$

$* * \mathrm{p}<.01$

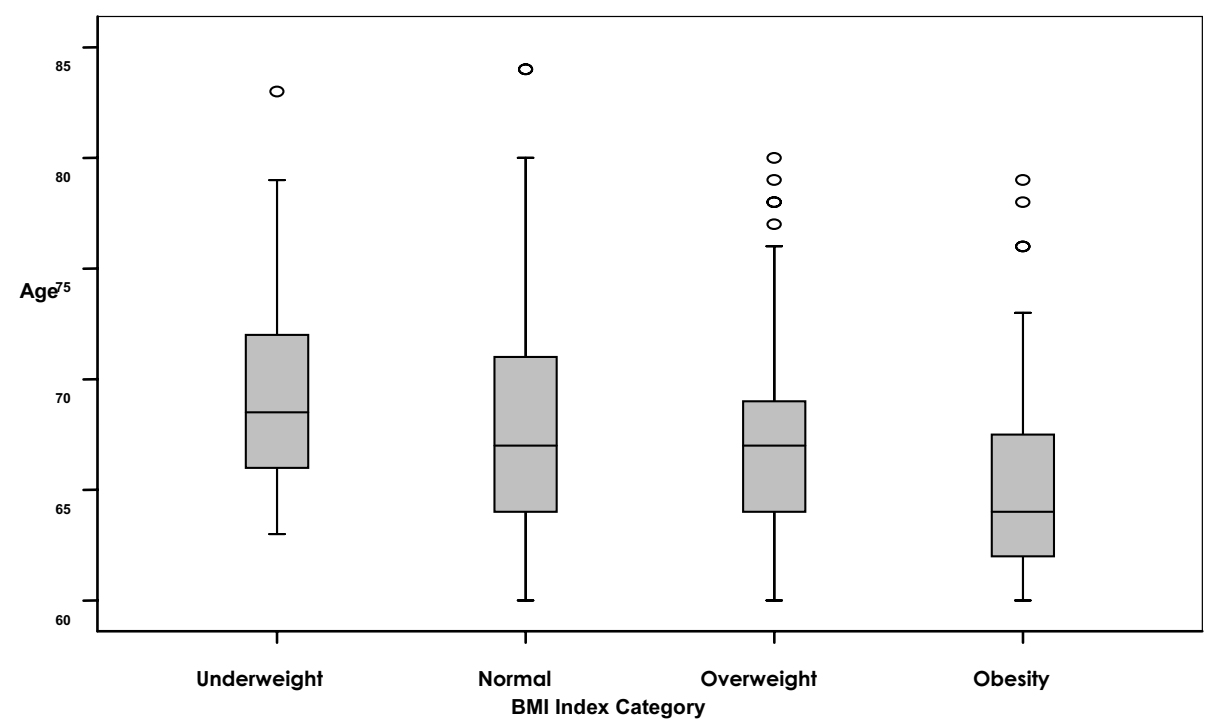

Figure 1. Box-and-Whisker Plot for Body Mass Index (BMI) category and age among older Malaysians (male and female) aged 60 years and above 